\title{
BACTERIOLOGICAL INVESTIGATIONS OF SUPPURATION IN THE LESIONS OF ERYTHEMA NODOSUM LEPROSUM
}

\author{
Masayasu Ito and Kaoru Ohira \\ (National Leprosarium, Nagashima Aiseien) \\ (Director: K. Mitsuda)
}

In this paper, the suppuration, which takes place in the course of Erythema nodosum leprosum, was studied, whether this lesion is caused by suppurative germs, excluding the leprosy bacillus.

The pus was collected aseptically 42 from the lesions of E. N. L. of which the overlying epidermis had not yet destructed, and cultured on goat-blood agar, aerobically in bouillon, anaerobically in Tarozzi's liver-liver bouillon, Kirchner's and Oka-Katakura's media for acid-fast bacilli.

The results of cultures on various media are as follows:

$\begin{array}{cccc}\text { Blood-agar } & \text { Bouillon } & \begin{array}{c}\text { Tarozzi's } \\ \text { Bouillon }\end{array} & \begin{array}{c}\text { Kirchner's and } \\ \text { Oka-Katakura's } \\ \text { Media }\end{array} \\ 39 & 29 & 23 & 24 \\ 38 & 26 & 21 & 24 \\ 1 & 3 & 2 & 0\end{array}$

The results of culture upon various media are showed negative, except three cases. Two cases Corynebacterium (not inoculated in Tarozzi's boillon) in bouillon, and Staphylococcus albus in bouillon and Tarozzi's bouillon. But these two cases produced no growth of organism upon blood-agar, therefore. these organism should be taken for nonpathogenic saprophytes which had mixed by chance in the management of culture. The last case supplied us Staphylococcus albus in bouillon and Tarozzi's bouillon and Staphylococcus albus and Staphylococcus aures upon blood-agar. In this case the very pus contained these organisms, but the significance of their existence in it is question.

Seeing from our experiments, no organism was found in the pus collected from the lesions, except those which were mixed in the management of culture or exist there by chance.

The suppuration of the lesions of erythema nodosum leprosum is independent upon the suppurative and other organisms which can be recognized by the above various media, but attributed to the other mechanism.

\section{癩性結節性紅斑化膿巢の細菌学的検索}

\author{
屒島儒生園 （園唇 光 田 健 輔） \\ 伊東正保大平馨
}

（昭和 29 年 5 月 29 日受稿）

（本報告の要旨は昭和 26 年 4 月, 第24回日本櫴学会に 於いて発表された。)

濑性結節性紅斑はその経過中に，時に化脤するととが
める。即ち，紅斑は軟化するが，急性炎症性症状は弱

く, 局所の熱感る著明でなく, 周囲に発赤腫脤の抎がる

ととも比較的少ない。そのまま吸収される場合と，表皮 
が破れて排脤する場合とめる。その膿は濃厚で, 通常の 化䔚の場合に比して粘䄯性が強い。之を整抹染色鏡見す れば, 多数の変性した多核白血球があり, 変性した瀨細

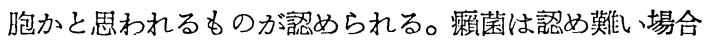
もおるが，之が証明される時は多少とも变性して居る。

斯かる化裳は, 化膿菌その他, 蟦菌以外の細菌の関与 によつて起るものであるか否かに就いての研究を私共は 知らないので，之に就いて娭索した成績を此処に報告す る。

\section{検 索 方 法}

1. 被検应例並びに材料採取法。

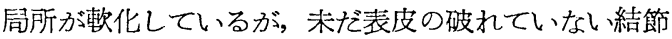
性紅玟を梌索した。急性炎症々状が想で著明で，周国に まで発赤が波及し, 明らかにFurunkelその他, 化膿菌に よる炎症と思われるものは除外した。又，表皮が既に破 れているものは, 雑菌の混入, 或いは二次感染を恐れて 除外した。

材料採取は可能な限りの無菌的操作の下に行つた。即 ち，皮䖉表面を沃丁を以つて隇菌した後， $2 / 2$ 注射針をつ けた減菌注射器で紫刺するか，或いは皮夙に小切開を加 えて，滅菌綿棒を以つて採取した膿を次に述へる培地に 坮荃した。

\section{2. 培 養 法}

垺養基には次のものを用いた。

（1）山羊血液然天培地による好気性埍養。

(2) ブイヨン培地による好気性培峑。

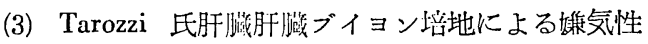
堵養。

（4）Kirchner 氏培地炎び阊・片倉氏培地による抗酸 性菌㟝養。

(1)，(2)の涪地を作るに当つて，その肉水は牛肉の出 液を以つてし， pH は7.2〜7.4に禣性した。肉エキス又 は乾懆粉末涪地は之を用いなかつた。

(1)，(2)，(3)は睜町器に収めた後, 毎日或いは隔日每に 推睍しつつ，1 週間前後培養した。(4)は硫酸処置 ( $5 \%$ 硫酸水 30 分, 毎分 $2,000 \sim 3,000$ 回転遠心沈测 30 分）を行 い,一部の例では未処置のま培地に植え, 毎週又は.隔 週铌に観祭しつつ, 約 2 ケ月培荃した。

肉眼的に培地に何等かの菌の発育を認めた時には，染 色鏡見，分離培荃及び純培荃を行つて，菌種の確定に務 めた。

\section{成 績}

検索総数は42例でもつて，その成績の総括は第一表に 示す如くでまる。との内の10例は著者の一人，伊真が国 立予防衛生研冧所非駿河療養所に在勤当時, 昭和 22 年 3 月から23年 5 月の間に駿河療養所の患者に就いて行つた もので，未だブロミン沿療の広く行われていない時期 で，被榆患者は何れも大風子油治潦を受けていたもので むる。他の 32 例は長島愛生園に於いて，昭和 25 年 6 月以 降に調ヘたもので, 既にプロミン,プロミン゙ール洷潦が 広く行われていた。

血液寒天培養を行つた 39 例中，1例を除き，38例に於 いて培地に何等の菌の発見も認められなかつた。ブイヨ ンでは29例中， 3 例を除き26例に於いて，Tarozzi 氏ブ イョンでは 23 例中，2 例を除き 21 例に於いて夫々菌の発 育は認められなかつた。抗酸性菌坾養の24例では（5 例 はKirchner境地のみ， 3 例は阅・片會湲地のみ，他の16 例は両者を併用した）全例に於いて菌の発育は認められ なかつた。

何れかの培地に菌の発育が認められた症例は第二表に 示す如き 3 例であつた。症例 E 25ではブイヨンにCoryne bacteriumが (此の例ではTarozzi氏ブイョンは非検), E 49ではブイョン及びTarozzi氏ブイョンに Staphylococcus albus が夫々発育したが，両例共，血液然天では何等の 菌の発育も認められなかつた。Staphylococcus albusは 雑菌として広く存在している菌であり，血液寒天には証 明出来なかつた点等から見て，之等の場合は操作中に迷 人した雑菌ではないかと思われる。若し膿の中に含まれ ていたものとしても，その菌数は政めて僅かのものでむ りそそれの化膿に及ぼした意義は無視しても良いもので 出ろら。

E 56では，血液舁天に於いても Staphylococcus aureus 及び albus の集落の発育を見たが，それ等の集落数は何 れも比較的少数で，一平船に夫々10筬内外づつであつ た。ブイヨン及びTarozzi氏ブイョンにはStaphylococcus albus が発育した。此の例では発育した㲘懆作中の迷 人菌と考之るよりは，膿の中に存在していたものと教之

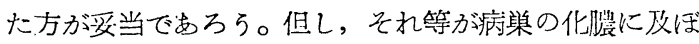
した意载は疑問である。

之を要するに，成績を全体として見る時，殆んど総て

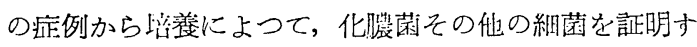

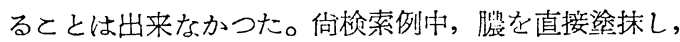
Ziehl-Neelsen 氏法で染色，その 20〜30 視野を鏡見した

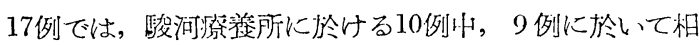
当多数の瀨菌と思われる抗酸性菌を認めたが，愛生園で 之を調べた7例中，3例に於いてのみ比較的少数の顁菌と 
思われる抗酸性菌を認めた。此の点に関する丽療盖所に

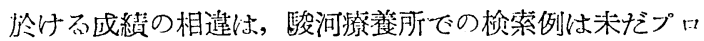
ミン治療が行われていなかつたので，大栭子注射を受け ていたもので出り, 要生園で調べた時には, 既にプロミ ン及びその類似薬が広く用いられ，梌索例は何れも相当 期間, その治療を受けていたものであるととに起因する のではなかろらか。

份，鏡見した全例に於いて，上記抗酸性菌以外には細 菌体と思われるものを認めるととは出来なかつた。

\section{考案}

結節性紅斑化膿栄の膿から，私共の用いた培養法によ つて,例外的に偶在菌,或いは操作中に迷大した雑菌と，思 われるものを除いては, 殆んど総ての検索例から何等の 細菌を証明し得なかつた。とのととは, 結節性紅斑の化 膿は，化膿菌その他，私共が用いた培地に発育し得る細 菌の関与するものではなく，その化膿の成因は全く他に めるととを示するのである。

私共は瀨患者の大風子油注射による化膿巣の細菌学的 検索を行つて (1), 従来, 一部に信ぜられていたように， 大風子油注射による化膿は無菌的に起るものではなく， 膿中には每常，化脤菌を主とする細菌か存在するととを 知つた。それととれとを対比するととは與味あるるのと 思われる。

\section{結論}

末たこ破れていない、霹性結節性紅斑化膿巣の膿を42例に 就いて，血液察天，ブイョン，Tarozzi氏肝茐ブイョン， Kirchner氏坮地及び阊・片倉氏培地を用いて，好気性， 娳気性並びに好酸性菌塧養による細菌学的検索を行つた 結果, 例外的に偶在菌, 或いは操作中の迷入雑菌と思わ れるものを除いた大多数の症例に於いて，何等の細菌を 証明し得なかつた。

即ち，顆性結節性紅斑の化膿は，化膿菌その他,私共が 用いた培養法によつて証明し得る細菌は，通常之に関与 するものではなく，その化膿の成因は他は存するととを 知つた。

（稿を終るに臨み，光田園唇の御指導，御校閲と， 同僚諸氏の御協力に梁謝する。）

\section{交献}

1）伊東正保：大風子油化膿巣の細菌学的検索, 長 島紀要に発表予定。
倠 1 或

\begin{tabular}{|c|c|c|c|c|}
\hline $\begin{array}{l}\text { 滔 地 } \\
\text { 結 果 }\end{array}$ & 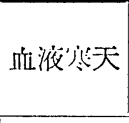 & ブイヨン & $\begin{array}{l}\text { Tarozzi氏 } \\
\text { ブイヨン }\end{array}$ & $\begin{array}{l}\text { Kirchuer } \\
\text { 氏渻地及 } \\
\text { び间・片 } \\
\text { 倉氏垛地 }\end{array}$ \\
\hline 検查件数 & 39 & 29 & 23 & 24 \\
\hline 菌発育(一) & 38 & 26 & 21 & 24 \\
\hline 菌発育(十) & 1 & 3 & 2 & 0 \\
\hline
\end{tabular}

第 2 表

\begin{tabular}{|c|c|c|c|c|}
\hline 症 例 & 血液短天 & ブイヨン & $\begin{array}{c}\text { Tarozzi氏 } \\
\text { ブイヨン }\end{array}$ & $\begin{array}{l}\text { Kirchner } \\
\text { 氏l地地及 } \\
\text { び滋・片 } \\
\text { 倉氏㠺地 }\end{array}$ \\
\hline E 25 & $(-)$ & $\begin{array}{l}\text { Coryneb } \\
\text { act. }\end{array}$ & & $(-)$ \\
\hline E 49 & $(-)$ & $\begin{array}{r}\text { Staphyloc. } \\
\text { albus }\end{array}$ & $\begin{array}{r}\text { Staphyloc. } \\
\text { albus }\end{array}$ & $(-)$ \\
\hline E 56 & $\begin{array}{r}\text { Staphyloc. } \\
\text { aureus } \\
\text { Staphyloc. } \\
\text { albus }\end{array}$ & $\begin{array}{r}\text { Staphyloc. } \\
\text { albus }\end{array}$ & $\begin{array}{r}\text { Staphyloc. } \\
\text { albus }\end{array}$ & $(-)$ \\
\hline
\end{tabular}

